\title{
NÄKÖKULMIA VERKKOPEDAGOGIIKKAAN
}

\author{
Pekka Kalli
}

Olemme verkkopedagogiikassa läpimurron kynnyksellä, kirjoittaa Pekka Kalli tehdessään lukijan löydöksiä neljästä hiljattain ilmestyneestä, verkkopedagogiikkaa käsittelevästä kirjasta. Silti tietoverkkojen käyttö muistuttaa vielä kaivolla käyntiä. Kaivo voi olla kaukana, ämpäri liian suuri, pieni tai vuotava.

$\mathrm{O}$ nko nyt koittanut verkko-oppimisen läpimurron aika? Viime vuosisadalla, tarkemmin vuonna 1988, vierailin Helsingin kauppakorkeakoulussa tutustumassa tietokoneavusteisen opetuksen (TAO) ihmeisiin. Silloin tietokoneavusteisen opetuksen (TAO) "grand (not so old) man" Veli-Pekka Lifländer ennakoi, että TAO lyö itsensä läpi muutamassa vuodessa. Kieltenopetuksessa ja musiikinopetuksessa näinkin jotain todellisia muutoksia (tosin ei kovin laajalla rintamalla), mutta muutoin kehitys on ollut silloisesta näkökulmasta katsottuna yllättävän hidasta. Lifländer ei ollut ainoa joka erehtyi TAO:n toteutumisessa. Vuoden 1988 jälkeen on tapahtunut paljon. Termi TAO ei juurikaan ole käytössä; nyt puhutaan verkkopohjaisten oppimisympäristöjen rakentamisesta.

Sattumalta myös Jouni Immonen aloittaa artikkelinsa Kirjeopetuksestaverkko-opiskelunn. Etäopetuksen neljä sukupolvea (teoksessa Matikainen \& Manninen 2000, 15-28) muisteluksella vuodelta 1988. Tuolloin Yhdysvaltalaisen Northern Illinoisin yliopiston kasvatustieteellisen tiedekunnan apulaisprofessori Dennis D. Gooler oli suomenvierailunsa yhteydessä esittänyt vision, jossa tu- levaisuudessa tieto kulkee yhtä helposti kuin vesi vesijohtojärjestelmässä. Gooler oli piirtänyt vesisäiliötä muistuttavan "tietotankin", josta johdot kulkeutuvat koteihin ja kouluihin, kirjastoihin ja työpaikoille.

Toko tieto vihdoin alkaa virrata Goolerin visiJon mukaisesti? Ainakin Immonen väittää niin. Goolerin vertausta jatkaen, meillä siis on tietotorneja (vrt. vesitorni), tiedonpuhdistuslaitteitta, toimiva tieto(johto)verkko, jätetiedon käsittelyjärjestelmä ja ennen kaikkea: avaamalla tietohanan, me voimme luottaa siihen, että saamme käyttökelpoista, puhdasta, hajutuntoa ja mautonta tietoa.

Jokainen, joka tietoverkkoja on käyttänyt tietää, että näin ei ole. Tilanne muistuttaa enemmän kaivolla käyntiä. Joskus kaivon etsiminen vie oman aikansa, usein se on kaukana tai vaikean matkan takana, ämpäri on liian suuri kannettavaksi, liian pieni että siihen mahtuisi tarvittavaa määrää tai sitten siinä on niin iso reikä, että tieto ei koskaan tule perille. Joskus myös kaivon vesi on saastunutta, juomakelvotonta tai koko kaivo on kuivunut (URL NOT FOUND). 


\section{KA T S A U K S I A}

Mutta olemmeko nyt murroksen kynnyksellä? Minkälaisia näkökulmia tarjoavat viimeaikoina ilmestyneet alan kirjat tietohuoltoalan ammattilaisille, tietorakennusinsinööreille (tekniikka), putkimiehille (verkkopedagogit, sisältötuottajat, opettajat), tietohygieniasta vastaaville (oppilaitokset, opetushallinto) ja tiedon valistuneille kuluttajille (opettajat ja oppijat)?

$\mathrm{L}$ aajin ja teoreettisesti kunnianhimoisin tähänastisessa suomenkielisessä kirjallisuudessa on Janne Matikaisen ja Jyri Mannisen toimittama Aikuiskoulutus verkossa. Verkkopohjaisten oppimisympäristöjen teoriaaja käytäntöä (Matikainen \& Manninen 2000). Maltillisen selkeää pohdintaa ja neuvoja verkkokurssien rakentamiseen tarjoaa puolestaan Kari Kiviniemen Johdatus verkkopedagogiikkaan (Kiviniemi 2000). Lyhyen ytimekkäästi ja insinöörimäisesti, mutta samalla pedagogisesti viisaasti tarjoaa apuaan Veli-Pekka Lifländer kirjassaan Verkko-oppiminen. Yhteistoiminnallinen projektioppiminen verkossa (Lifländer 1999). Jyväskylän tietotekniikkainstituutin tutkijat Korpi ym. ovat puolestaan tuottaneet oppimisympäristöistä vertailevan raportin Virtuaalinen oppimisympäristökoulutustajärjestävän organisaationtyövälineenä (Korpi ym. 2000). Raportin otsikko ei ole kuitenkaan kovin onnistunut. Mielestäni olisi muutoinkin tarkoituksenmukaista rajata virtuaali -sanan käyttöä. Luontevasti se soveltuu oppimisympäristöihin, jotka ovat oikeasti jollakin tavalla virtuaalisia (keinotekoisia), kuten oppimistarkoituksiin tuotetut simulaatiot ja oppimissimulaattorit. Oppimateriaalin ja oppimisen edistäminen verkkopohjaisesti ei luo virtuaalista ympäristöä (vai kokevatko ihmiset tietoverkot niin keinotekoisiksi nykymaailmassa). Myös oppimisympäristöön kuuluu verkkoympäristön lisäksi useimmiten paljon muuta sosiaalista, psyykkistä, fyysistä ja taloudellista ympäristöä. Termi verkkopohjainen oppimisympäristö on siksi hyvä: se on riittävän avoin erilaisille ratkaisuille.

Verkkopohjaisen oppimisen ydin on oppimiskäsityksessä. Tämä ydin ei poikkea millään olennaisella tavalla muusta oppimisesta. Oppiminen on oppijan prosessi; kaikki muu on ulkoista ja suhteessa siihen. Verkkopohjaista oppimista voidaan tarkastella muistakin näkökulmista. Hallin- nollinen, tekninen ja sisällöllinen ovat kolme muuta tärkeää asiaa, joiden tulee olla kunnossa, kun verkkokursseja tarjotaan opiskelijalle. Pedagogisen näkökulman tulisi kuitenkin olla ydin, koska muutoin syntyy paljon melua tyhjästä ja itse oppiminen jää vajaaksi tai ohjautuu verkkojen ulkopuolelle.

\section{Aikuisdidaktisen kentän jäsennys}

$\mathrm{M}^{2}$ atikaisen ja Mannisen kirjan kirjoittajat jäsentävät aikuisdidaktisen kentän viiteen lähestymistapaan. Opetusteknologinen, kognitiivinen, konstruktivistinen, humanistinen ja kriittinen lähestymistapa ovat erilaisia vaihtoehtoja, jotka heijastuvat myös verkkopohjaisten oppimisympäristöjen toteutuksessa. Aikuisdidaktiikassa vallitseva eklektismi ja moniarvoisuus merkitsee kuitenkin sitä, että useimmissa toteutuksissa ei ole tietoista pedagogista ja didaktista näkemystä taustalla. Toisaalta toteutuksen tasolla eri didaktiset lähestymistavat voivat toimia enemmänkin välineellisesti. Ne ovat kuin työkaluja, jotka otetaan käyttöön tarvittaessa. Manninen ja Pesonen viittaavatkin tähän toteamuksella, että polkupyöräilyä oppii parhaiten 'learning by doing' -periaatteella, auton moottorin toimintaperiaatteen engeströmiläiseen orientaatioperustaan pohjautuvalla kurssilla, sosiaalisiin rooleihin ja arvoihin liittyvää vapautumista radikaaliin humanismiin perustuvissa kommunikatiivista oppimista tukevissa ympäristöissä... (Manninen \&Pesonen 2000, 67) Verkkopohjaisten oppimisympäristöjen rakentamisessa jujuna, niin kuin oppimisprosessien ohjaamisessa yleensäkin, näyt- 
tää siis olevan entistä olennaisempaa sen kontekstin hahmottaminen, jossa oppiminen tapahtuu. Kurssien muunneltavuus, avoimuus ja räätälöinti oppijan näkökulman mukaiseksi on myös verkkopohjaisessa opiskelussa tärkeää. Opettajilta ja kurssien toteuttajilta tämä edellyttää ratkaisukeskeisiä työtapoja. Teoreettisesti tämä ei voine tapahtua kuin konstruktivistisesta ja kontekstuaalisesta näkökulmasta eli siten, että kaikki aiemmat näkökulmat ja työmenetelmät sulatetaan osaksi nykyistä modernia kasvatusajattelua. Oppimisen sisältö, syvyys ja taso määrittävät myös verkkopohjaisen opiskelun rakenteen ja käytettävien menetelmien tarpeen.

Siinä missä Matikanen ja Manninen kartoittavat aikuisdidaktiikan koko kenttää, tyytyvät Kiviniemi ja Lifländer suppeampiin näkökulmiin. Kiviniemi nostaa esiin verkko-oppimisprosessin oppimistehtävien pohjalta, korostaa oppijan itseohjautuvuuden tarvetta, yhteistoiminnallisuuden mahdollisuuksia ja tukijärjestelmien toimivuutta. Lifländer taas olettaa lukijaltaan pedagogisia perusvalmiuksia ja ottaa tarkastelun lähtökohdaksi yhteistoiminnallisen projektioppimisen tukemisen verkkopohjaisella ratkaisulla.

\section{Käytännön ohjeet}

$\mathrm{K}$ aikissa kirjoissa annetaan käytännön ohjeita zerkkokurssien suunnittelusta. Lifländer on kaikkein yksityiskohtaisin. Hänen kirjastaan voi löytää mallin opetussuunnitelman yleisen ja erityisen osan toteuttamiseksi. Lifländer lähestyy verkkokurssin suunnittelua orientaatioperustaisesti ja tietylle tiedossa olevalle ryhmälle suunnatusta projektista lähtien. Kiviniemi lähestyy asiaa suljetun ja avoimen oppimisympäristön näkökulmasta. Kiviniemi esittää myös kurssin suunnitteluun laaja-alaisen näkökulman aina kurssin tarpeellisuuden arvioinnista sen ylläpitoon ja päivitykseen saakka. Korpi ym:n tarkastelussa taas on hyvänä näkökulmana koulutusorganisaation tasolla tapahtuvien muutosten tarpeellisuuden tarkastelu.

Verkkokurssien toteuttamisen ohjeistuksissa on mielenkiintoinen ristiriita. Toisaalta korostetaan verkossa tapahtuvan oppimisen lisäarvon olevan muun muassa siinä, että verkossa voidaan käyttää multimediaelementtejä; siksi on vältettävä vain tekstipohjaisen aineiston viemistä ja vanhan oppimateriaalin uusintamista sähköisessä muodossa. Toisaalta, jotta verkkopohjainen aineisto olisi mahdollisimman laajasti tavoitettavissa, sen tulisi olla sellaisessa muodossa, että aineiston voi avata myös vaatimattomilla välineillä ja ohjelmistorepertuaarilla.

Pedagogisen lisäarvon saavuttaminen on siten usein kiinni tekniikan kehittyneisyydestä. Tämä on käytännössä erittäin tärkeä näkökulma: verkko-oppimisen edellytysten ketjun täytyy olla ehyt: hallinto, sisältö, tekniikka, pedagogiikka. Usein loppukäyttäjältä, oppijalta, edellytetään aivan liian paljon tiedon saannin kannalta tarvittavia omia välineitä ja taitoa muokata, puhdistaa ja ottaa käyttöön oppimisen kannalta tärkeitä aineksia. Tilanne on usein sen kaltainen, kuin jos vesijohtoveteen johdettaisiin raakavettä ja sanottaisiin: puhdista se itse kotonasi.

\section{Tulevais u us}

Kiviniemen mukaan olemme olleet todistamassa eräänlaistaverkkopedagogisen toiminnan alkuräjähdystä (Kiviniemi 2000,150). Hän päätyy viisaasti kuitenkin toteamaan, yhdensuuntaisesti Matikaisen ja Mannisen pohdintojen kanssa, että $y k s i t-$ täisenopettajannäkemys oppimisestajaopettamisestaon ratkaisevaamyös verkkokurssin organisoinnin kannalta.(mt.151) Minkälaisia näkemyksiä opettajat omaksuvat on sekä yksilöllinen että yhteiskunnallis-yhteisöllinen kysymys. Jokaisen opettajan on ratkaistava, minkälaisia opetuskäytäntöjä hän vie verkkoympäristöön. Opettajankoulutuslaitosten on ratkaistava, minkälaisia oppimisteoreettisia näkemyksiä ne tukevat pedagogisissa opinnoissa ja yhteiskunnan päättävissä asemissa olevat ratkaisevat, minkälaisia hankkeita tuetaan niin taloudellisesti kuin henkisestikin.

$T_{1}$ eknisesti kaikki uudet verkkopohjaiset oppimisympäristöt vaativat vielä paljon kehittelyä, jotta niiden käyttö olisi todella sujuvaa. Korpi ym. toteavat viisaasti, että olennaista ei 
ole se, minkälainen käyttöön otettava yksittäinen oppimisympäristötuote on, vaan pääpaino on siinä, miten opetus järjestetään. Tämä järjestäminen puolestaan vaikuttaa toivottavasti siihen, miten ympäristöt kehittyvät teknisesti: suosivatko ne esimerkiksi aineistopainotteista, testeihin ja kokeisiin suuntaavaa oppimista vai vuorovaikutteista ja yhteistoiminnallista oppimista.

Verkkopohjaisuus ja oppilaitosten ja oppijoiden verkostoituminen kansallisesti ja kansainvälisesti mahdollistavat ihmisten kohtaamisen ja oppimisen uudella tavalla. Kohtaamisen ja oppimisen laadun ja sisällön määrää edelleen ihminen: edellytykset, näkemykset ja halu yhteiskunnan inhimilliseksi kehittämiseksi kasvaa näkemyksestä, jossa tieteet, taide ja uskomukset ovat tapa ymmärtää maailmaa. Tekniikan kehittäminen antaa meille lisää välineitä tämän ymmärryksen kehittämiseen, ei automaattisesti vaan sitä oikein ja hyvin käyttämällä. Verkostopohjainen oppiminen on pedagogiikalle omena, jota puremalla saamme tiedon hyvästä ja pahasta yhdellä kertaa. Purematta ei saa elämän makua, puremalla saa välttämättä niin hyvän kuin pahan. Verkkopohjaisuus mahdollistaa, raamatullisissa vertauksissa pysyäkseni, ei vain veden, vaan myös leivän ja- kamisen, ei vain viidelle tuhannelle miehelle, vaan lähes rajattomasti (myös naisille ja lapsille). Leivän tuoreus, maku ja laatu ratkaisee sen, kuka sitä maistaa. Ja joillekin, tiedät kai, maistuu vain sipsit ja tiedät kai, mikä.

\section{Kirjallisuus}

KIVINIEMI, Kari, Johdatus verkkopedagogiikkaan. Keski-Pohjanmaan Ammattikorkeakoulu, Kokkola 2000

KORPI, Niemi, Ovaskainen, Siekkinen ja Junttila, Virtuaalinen oppimisympäristö koulutusta järjestävän organisaation työvälineenä, Jyväskylän yliopisto, Tietotekniikan tutkimusinstituutti, julkaisuja 7/2000

LIFLÄNDER, Veli-Pekka, Verkko-oppiminen. Yhteistoiminnallinen projektioppiminen verkossa. Edita, Helsinki 1999

MATIKAINEN, Janne \& Manninen, Jyri (toim.), Aikuiskoulutus verkossa. Verkkopohjaisten oppimisympäristöjen teoriaa ja käytäntöä. Helsingin yliopiston Lahden tutkimus- ja koulutuskeskus. Tampere 2000

Janne Matikaisen ja Jyri Mannisen teoksesta Aikuiskoulutus verkossa (2000) ilmestyy seikkaperäinen arvio lehden seuraavassa numerossa. Pahoittelemme, että tilanpuutteen vuoksi sitä ei pystytty mahduttamaan jo käsillä olevaan numeroomme. Välähdyksiä arviosta on nähtävissä ennakkoon myös lehden kotisivulla www.kvs.fi/Aikuiskasvatus 